\title{
Methods of Obtaining Nickel Molybdates and Composites of Molybdate/Carbon Material for Electrodes of Hybrid Supercapacitors
}

\author{
Vasyl Stefanyk Precarpathian National University, Ivano-Frankivsk,Ukraine, khemiiolha@ gmail.com
}

\begin{abstract}
Nickel molybdate due to its electronic configuration, stable crystalline framework, oxidation-reduction behaviour displays perfect physical and chemical properties and rather high electrical conductivity that altogether lets the material display high total capacity. The research work classified modern methods of obtaining nickel molibdates and composites with carbon material on their basis. We have analyzed the fundamental stages of hydrothermal, microwave synthesis, ultrasonic dispersion, mechano-chemical, sol-gel method and chemical precipitation method. The influence of different synthesis conditions on phase structure, morphology, physical and electrochemical properties of material was displayed.
\end{abstract}

Keywords: nickel molibdate, supercapacitor, synthesis, specific capacitance, carbon material.

Received 13 November 2020; Accepted 15 December 2020.

\section{Introduction}

Nanostructured materials deserve much of attention due to their unique electrochemical, optical, magnetic, electrical and photocatalytic properties [1, 2]. Nowadays among different ways of applying nanomaterials there is a significant increase of their application in energystorage devices due to the increasing public demand for them. Lithium batteries and supercapacitors are extensively used as energy-storage devices, with the first having higher energy but less power and needing more time for charging and discharging [3, 4]. Supercapacitors, in their turn prove to be very promising devices because they charge quickly, safe to use (charge collection is taking place at rigid bodies, not resulting from chemical reactions like in lithium batteries), extreme temperatures and physical damage resistance, and commercial supercapacitors also ensure about 1 million charge cycles and $98 \%$ energy output efficiency. According to energy containment mechanism by electrode materials, supercapacitors are divided into two types: electric double layer capacitors (EDL) and pseudocapacitors. Supercapacitors with EDL accumulate charges at electrode/electrolyte interface. The most typical electrode materials in EDL capacitors are carbon materials with big surface [5], such as activated carbon material, carbon fiber, graphene, carbon nanotubes, aerogels, etc. Pseudocapacitors primarily use quick reversible oxidation-reduction reactions in order to accumulate charges between an electrode and an electrolyte, with known electrode materials as metal oxides and conductive polymers [6-8], with $\mathrm{RuO}_{2}$ and $\mathrm{MnO}_{2}$ being the most investigated materials, but their application is limited by high toxicity and poor conductivity $[9,10]$. In order to obtain high total output performance of supercapacitors, thorough research is being done, as well as regarding other metal oxides, binary metal oxides, altogether with sulfides [11, 12]. But, because of poor own electroconductivity of metal oxides and small diffusion distance of electrolyte ions into electrodes (about $20 \mathrm{~nm}$ ), the biggest part of electroactive substances does not take part in effective faradic reactions. That is why in most cases it is just the surface layer of electroactive materials that contributes to the total storage device capacity $[13,14]$.

Binary metal oxides have higher total capacity 
compared to metal oxides due to their numerous oxidation rates and higher electroconductivity. Of these it is worth mentioning metal molibdates - the class of mixed metal oxides that is used in supercapacitors [15, $16]$, electronic devices $[17,18]$ and catalytic converters [19]. The atoms of molybdenum in such compounding may have different coordination numbers, resulting in forming two molibdates crystalline frameworks: the sheelite framework and the wolframite framework. The general formula is $\mathrm{AMoO}_{4}$ (where $\mathrm{A}=\mathrm{Ni}, \mathrm{Co}, \mathrm{Fe}, \mathrm{Cu}$ ). The wolframite structure is more typical for divalent cationic molibdates with ionic radius less than $0.77 \AA$ $[20,21]$. Compared to other molibdates, $\mathrm{NiMoO}_{4}$ due to its electronic configuration, stable crystalline framework, oxidation-reduction behaviour displays perfect physical and chemical properties and rather high electrical conductivity (about $10^{-6} \mathrm{Om}^{-1} \mathrm{sm}^{-1}$ ), because of molybdenum, associated with high electrochemical activity of nickel that altogether lets the material display high total capacity [22]. $\mathrm{NiMoO}_{4}$ may exist in several

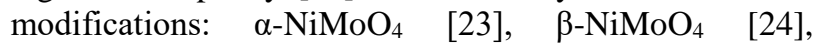
$\mathrm{NiMoO}_{4}$-(II) under high pressure [25] and hydrates $\mathrm{NiMoO}_{4} \cdot \mathrm{nH}_{2} \mathrm{O}$ [26]. Both phases $(\alpha$ and $\beta)$ are monoclinic with different space group $I 2 / m$ (JCPDS, 33-0948) and $C 2 / m$ (JCPDS, 45-0142). Structural units that make up $\alpha-\mathrm{NiMoO}_{4}$ are octahedrons $\mathrm{NiO}_{6}$ and $\mathrm{MoO}_{6}$, dividing their edges and forming chains. $\beta-\mathrm{NiMoO}_{4}$ formation consists of molybdate tetrahedrons that share angles with four different nickel octahedrons.

Despite all the above-mentioned advantages of $\mathrm{NiMoO}_{4}$ after multiple redox reactions the structure of molibdates is prone to destruction that leads to instability and the reduction of coulombic efficiency [27] and respectfully limits its further industrial application. That is why we need different strategies for improvement their output performance including regulation and morphology optimization, structure and the process of obtaining $\mathrm{NiMoO}_{4}$ material. One of the ways to avoid the abovementioned complications is combining $\mathrm{NiMoO}_{4}$ with carbon materials that have high conductivity and high specific surface area, thanks to which the composite has better capacitive characteristics compared to separate material [28, 29].

We have classified the methods of obtaining nickel molibdates, analyzed the influence of different synthesis conditions on phase structure, morphology, physical and electrochemical properties of material. The paper contains the survey of primary modes of obtaining $\mathrm{NiMoO}_{4}$ and composites with carbon material on its basis and compared output performance of the given materials in the capacity of supercapacitors of electrodes.

\section{Hydrothermal synthesis}

The foundation of hydrothermal synthesis is high dissolubility of non-organic substances in water at high temperatures and pressure with further crystallization of dissolved material from liquid phase. The control over vapour pressure, temperature and time of reaction makes it possible to increase the speed of spontaneous nucleation and obtain narrow distribution of nanoparticles according to their size.
Hydrothermal synthesis of nickel molibdates is aimed at obtaining material with different morphology and controlled size of nanoparticles at high pressure and temperature of $120-180^{\circ} \mathrm{C}$ in autoclave. The authors [30] described the general synthesis of nano/ microcrystals of nickel, cobalt and manganese molybdates and investigated the effect of temperature and $\mathrm{pH}$ on the final reaction products. It was found that hydrothermal treatment of the amorphous dispersion $\mathrm{M}\left(\mathrm{NO}_{3}\right)_{2}(\mathrm{M}=\mathrm{Co}, \mathrm{Ni}, \mathrm{Mn})$ and $\left(\mathrm{NH}_{4}\right)_{6} \mathrm{Mo}_{7} \mathrm{O}_{24}$ at $140{ }^{\circ} \mathrm{C}$ for $12 \mathrm{~h}$ leads to the formation of a pure phase $\mathrm{MMoO}_{4} \cdot n \mathrm{H}_{2} \mathrm{O}$. Mixing precursors with final $\mathrm{pH} 4.5$, after hydrothermal treatment did not produce the desired materials. The mixture $\mathrm{NiMoO}_{4} \cdot \mathrm{H}_{2} \mathrm{O}$ and $\mathrm{Ni}_{2}\left(\mathrm{NO}_{3}\right)_{2}(\mathrm{OH})_{2} \cdot ? \mathrm{H}_{2} \mathrm{O}$ (JCPDS: 27-0939) was obtained when the $\mathrm{pH}$ of the solution was adjusted to 5 by adding aqueous ammonia $(25 \%)$. At $\mathrm{pH}=7$, pure $\mathrm{NiMoO}_{4} \cdot \mathrm{H}_{2} \mathrm{O}$ with a "flower-like" structure is obtained. The monoclinic $\alpha-\mathrm{NiMoO}_{4}$ phase was obtained after calcination of $\mathrm{NiMoO}_{4} \mathrm{H}_{2} \mathrm{O}$ at $550{ }^{\circ} \mathrm{C}$.

Nanospheres $\mathrm{NiMoO}_{4}$ with a diameter of about $2.5 \mu \mathrm{m}$ are composed of thin mesoporous nanosheets with a thickness of about $10-20 \mathrm{~nm}$ and nanorods with a diameter of about $80 \mathrm{~nm}$ and a length of $300 \mathrm{~nm}$ to $1 \mu \mathrm{m}$ (Fig. 1) were obtained in [31]. Sodium molybdate and nickel acetate were mixed in distilled water and kept in an autoclave at $140^{\circ} \mathrm{C}$ for $12 \mathrm{~h}$ to obtain nanospheres, and sodium molybdate and nickel hexanitrate were added to ethanol / distilled water ( $1: 1$ by volume) and kept in an autoclave under the same conditions to obtain nanorods. $\mathrm{NiMoO}_{4}$ nanospheres showed higher specific capacitance and better rate capability than nanorods in electrochemical studies due to larger surface area and higher electrical conductivity. Specific capacitances were 974.4, 920.8, 875.5, 859.1 and 821.4 F/g at currents of 1 , 2, 4, 6 and $10 \mathrm{~A} / \mathrm{g}$ respectively. The energy achieved $20.1 \mathrm{Wh} / \mathrm{kg}$ at a power of $2100 \mathrm{~W} / \mathrm{kg}$. Electrode based $\mathrm{NiMoO}_{4}$ nanospheres still showed specific capacitance of about $631.8 \mathrm{~F} / \mathrm{g}$ at a current of $5 \mathrm{~A} / \mathrm{g}$ after 2000 cycles.

$\mathrm{NiMoO}_{4}$ nanosheets and nanorods were grown [32] on four different types of conductive substrates (Ni foam, Ti foil, stainless steel foil and flexible graphite paper). Hydrothermal synthesis was carried out at $160^{\circ} \mathrm{C}$ for $6 \mathrm{~h}$. If only distilled water is used as the solvent, the nanorods of nickel molybdate are obtained, whereas when water / ethanol ( $1: 1$ by volume) is added as the solvent, the final product of the hydrothermal reaction is $\mathrm{NiMoO}_{4}$ nanosheets. The authors found that nickel molybdate nanosheets have a higher specific capacitance and good rate capability compared to nanorods. The asymmetric capacitor based on $\mathrm{NiMoO}_{4}$ nanosheets as a positive electrode and activated carbon as a negative electrode demonstrates stability to cycling in a wide potential range $1.7 \mathrm{~V}$ (the capacitance loss is about $14.3 \%$ after 10,000 cycles) and provides high energy of $60.9 \mathrm{Wh} / \mathrm{kg}$ at a power of $850 \mathrm{~W} / \mathrm{kg}$.

One-dimensional nanorods $\mathrm{NiMoO}_{4} \cdot \mathrm{xH}_{2} \mathrm{O}$ were obtained by hydrothermal method without the use of any organic surfactants and solvents, namely by dissolving nickel hexanitrate $\left(\mathrm{Ni}\left(\mathrm{NO}_{3}\right)_{2} \cdot 6 \mathrm{H}_{2} \mathrm{O}\right)$ and sodium molybdate $\left(\mathrm{Na}_{2} \mathrm{MoO}_{4}\right)$ in distilled water [33]. Aqueous ammonia was added to control the $\mathrm{pH}$ level. The solution was placed in an autoclave and kept for 2 hours at 

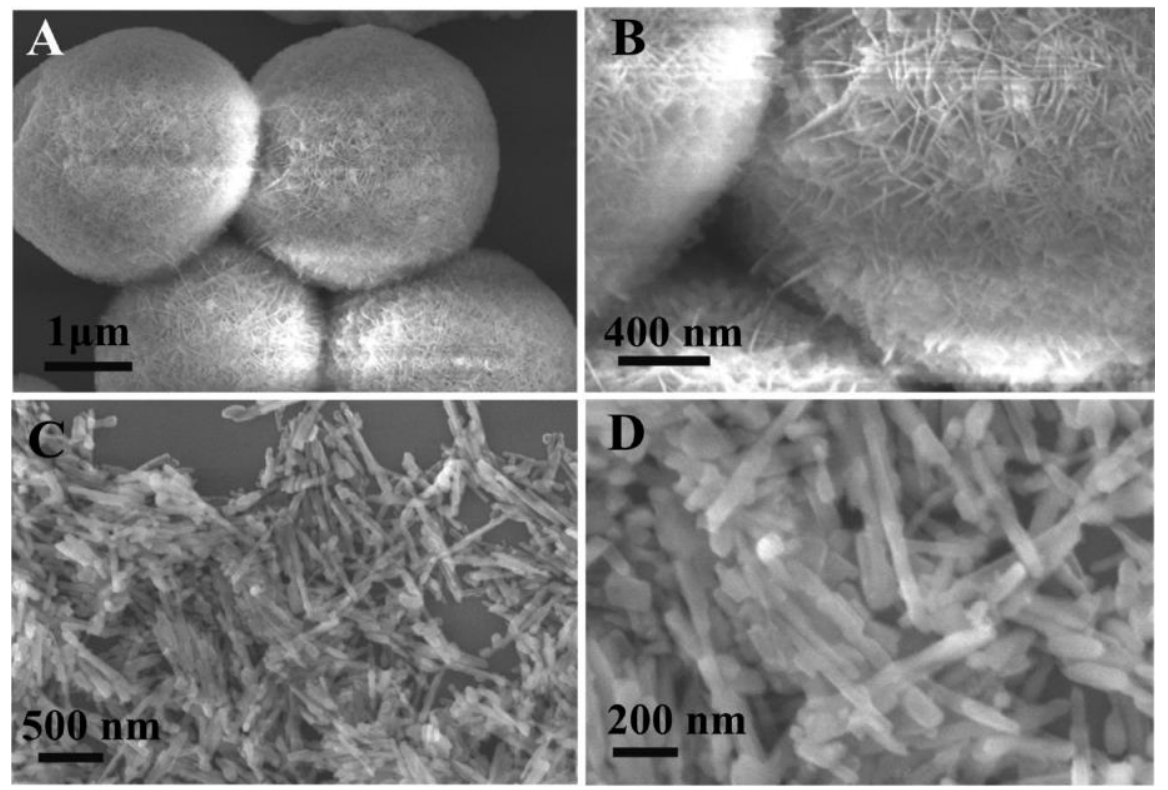

Fig.1. Typical SEM images of the $\mathrm{NiMoO}_{4}$ nanospheres at (A) low magnification and (B) high magnification and typical SEM images of the $\mathrm{NiMoO}_{4}$ nanorods at (C) low magnification and (D) high magnification [31].

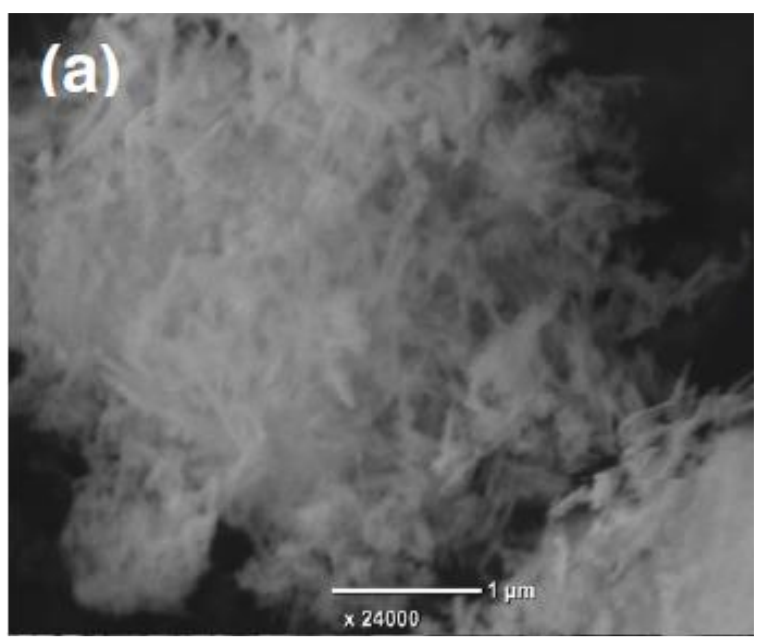

Fig.2. SEM image of hydrothermal synthesized $\mathrm{NiMoO}_{4} \cdot \mathrm{xH}_{2} \mathrm{O}$ nanorods [33].

$180{ }^{\circ} \mathrm{C}$. The SEM image of $\mathrm{NiMoO}_{4} \bullet \mathrm{xH}_{2} \mathrm{O}$ (Fig. 2) shows that the synthesized material has a "nanorod-like" structure. Nanorods with a diameter of $20-30 \mathrm{~nm}$ are loosely packed. The $\mathrm{NiMoO}_{4} \cdot \mathrm{xH}_{2} \mathrm{O}$ electrode showed a maximum specific capacitance $679 \mathrm{~F} / \mathrm{g}$ at $1 \mathrm{~mA} / \mathrm{cm}^{2}$.

A schematic illustration of the process of forming $\mathrm{NiMoO}_{4}$ nanorods is shown in Fig. 3 (a) [34]. At room temperature $\mathrm{Ni}^{2+} \mathrm{i} \mathrm{MoO}_{4}{ }^{2-}$ ions are neutralized in deionized water, forming a clear solution. In [34], the influence of heating time (1, 2, 4 and $6 \mathrm{~h}$ ) on the state and morphology of the final materials was investigated. The authors found that: nanorods $\mathrm{NiMoO}_{4}$ with an average length of $4.1 \mu \mathrm{m}$ are formed when the reaction proceeds at $160{ }^{\circ} \mathrm{C}$ for $1 \mathrm{~h}$ (Fig. 3 (b)). A longer reaction time increases the length of $\mathrm{NiMoO}_{4}$ nanorods to approximately $5.4 \mu \mathrm{m}, 6.1 \mu \mathrm{m}$ and $8.2 \mu \mathrm{m}$ for $2 \mathrm{~h}, 4 \mathrm{~h}$ and $6 \mathrm{~h}$, respectively. (Fig. 3, c-e). The electrode based on the synthesized material shows a high specific capacitance of $1102.2 \mathrm{~F} / \mathrm{g}$ at a current of $1 \mathrm{~A} / \mathrm{g}$, as well as excellent rate capability, maintaining $90 \%$ of the initial capacitance even after 1000 cycles.

The authors [35] obtained nanorods $\mathrm{NiMoO}_{4}$ of different degrees of crystallinity. Hydrothermal synthesis was performed at different temperatures of 120, 150 and $180{ }^{\circ} \mathrm{C}$ for time of 6,12 and 18 hours, respectively. After that samples were annealed at $500{ }^{\circ} \mathrm{C}$ for 3 hours. It was shown that the average size of $\mathrm{NiMoO}_{4}$ crystallites decreases with increasing temperature and reaction time. This can be explained by the fact that during the hydrothermal synthesis the hydrated form of $\mathrm{NiMoO}_{4}$ is first obtained. The number of water molecules associated to $\mathrm{NiMoO}_{4}$ largely depends on the reaction time and temperature. Hydrated water is removed gradually with a change in temperature and reaction time, which may cause a gradual decrease in the average crystal size of the synthesized $\mathrm{NiMoO}_{4}$. The authors found that $\mathrm{NiMoO}_{4}$ synthesized at $150{ }^{\circ} \mathrm{C}$ for 6 hours showed the best properties among other samples due to greater mesoporosity and optimal crystallinity. This provided greater penetration of electrolyte in the active material and the participation of all active centers nanorods $\mathrm{NiMoO}_{4}$ in the electrochemical reaction. The maximum specific capacitance of this sample was $594 \mathrm{~F} / \mathrm{g}$ at a current of $1 \mathrm{~A} / \mathrm{g}$.

$\mathrm{NiMoO}_{4}$ nanorods were obtained on a graphene sheets by hydrothermal method followed by calcination [36]. The electrode based on the graphene- $\mathrm{NiMoO}_{4}$ composite, prepared at a mass ratio of $1: 8$, showed a specific capacitance of $670 \mathrm{~F} / \mathrm{g}$ at a current of $0.3 \mathrm{~A} / \mathrm{g}$. After 3000 cycles, the electrode retained $88 \%$ of the initial capacitance at a current of $0.5 \mathrm{~A} / \mathrm{g}$ with Coulomb efficiency of $80 \%$. The study [37] presented the synthesis of the heterostructure of N-doped grapheme / $\mathrm{NiMoO}_{4}$. The hybrid composite achieves a specific capacitance of $1913 \mathrm{~F} / \mathrm{g}$ at a current of $1 \mathrm{~A} / \mathrm{g}$ combining high conductivity, a large specific surface area of 

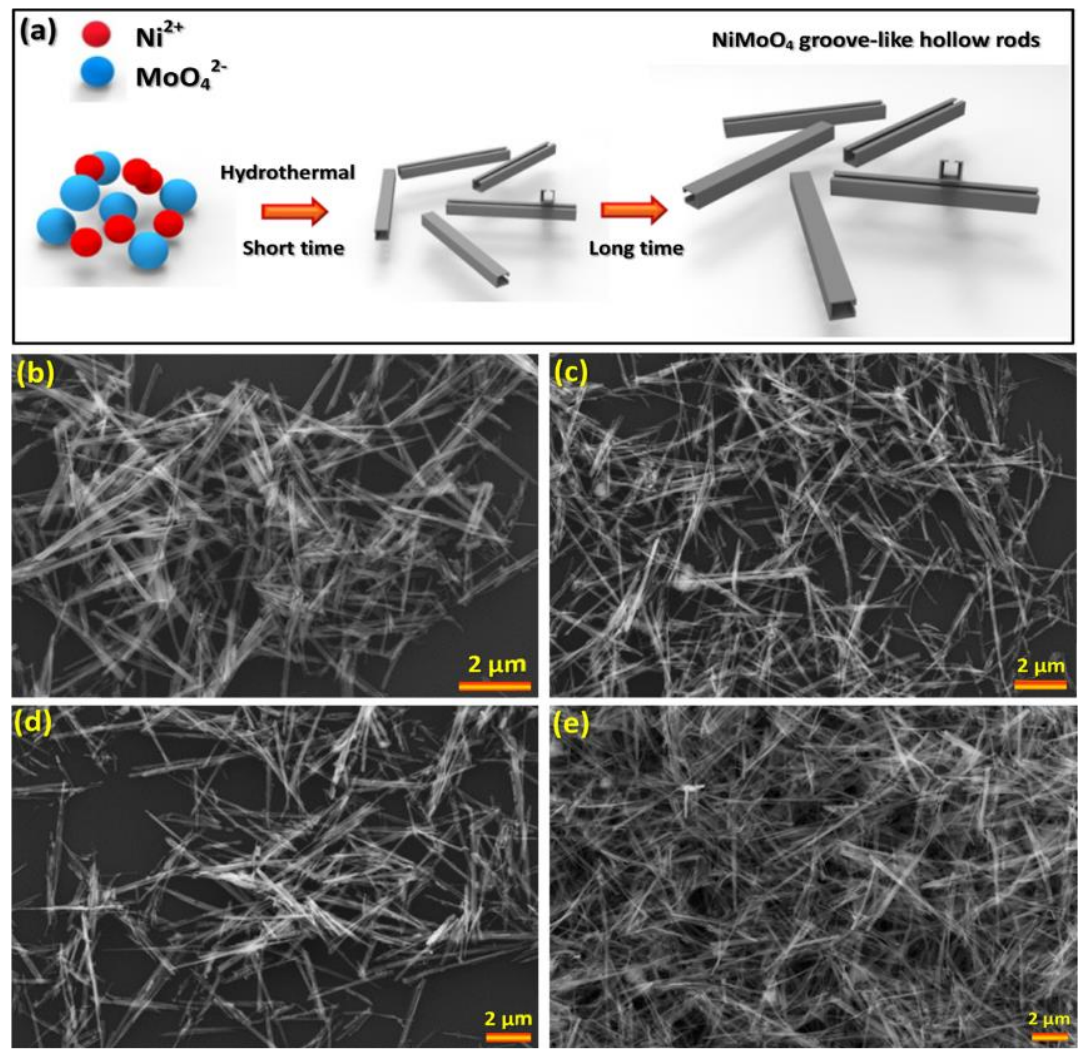

Fig. 3. (a) Schematic illustration of the formation process of $\mathrm{NiMoO}_{4}$-GHRs. FESEM images of $\mathrm{NiMoO}_{4}-\mathrm{GHRs}$ samples with hydrothermal treat times of (b) $1 \mathrm{~h}$, (c) $2 \mathrm{~h}$, (d) 4 hand (e) $6 \mathrm{~h} \mathrm{[34]}$
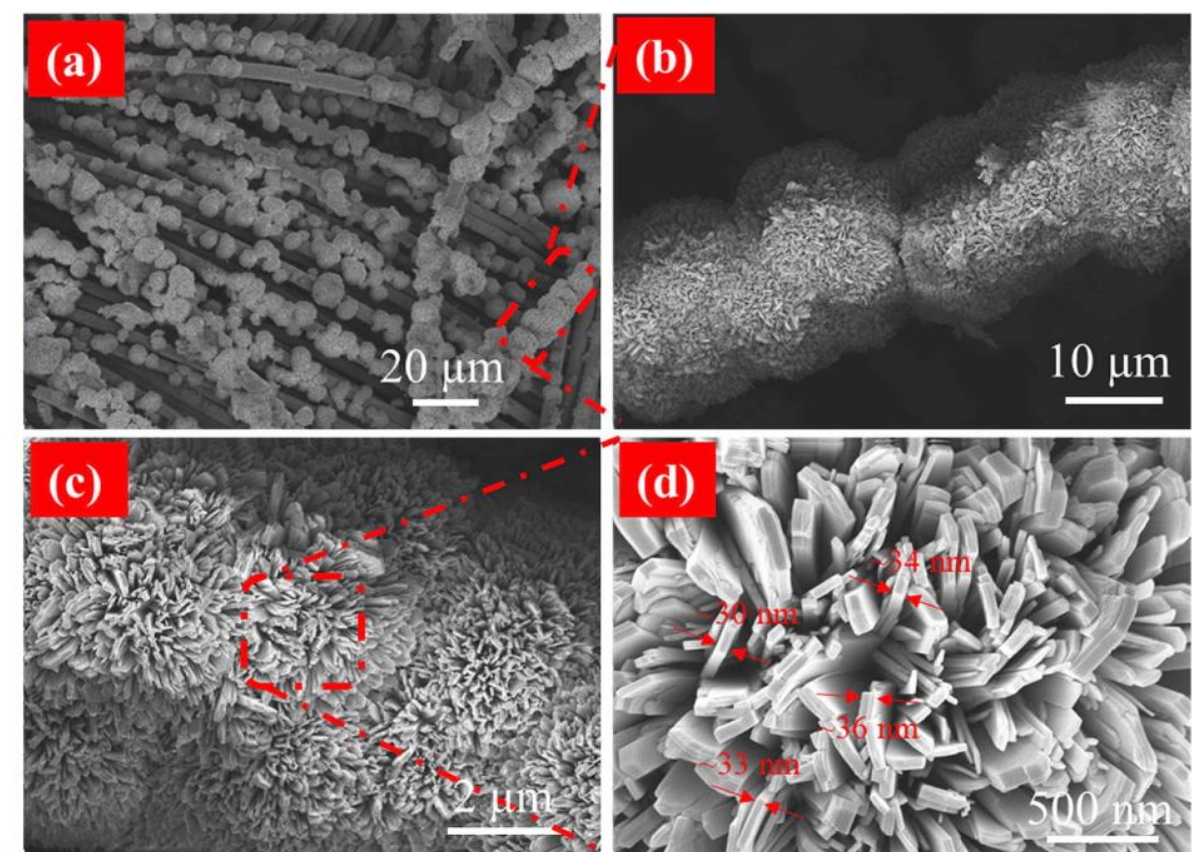

Fig.4. Morphological characterizations of NMO@CC electrode: (a) low resolution FE-SEM image, (b) selected part from Fig. (a). (c) High resolution FE-SEM image and (d) selected part from Fig. (c) [38].

graphene and reversible redox metal oxide. The asymmetric supercapacitor based on the nanocomposite as a positive electrode and the activated carbon material as a negative electrode shows a capacitance of $62.5 \mathrm{~F} / \mathrm{g}$ at a current of $0.5 \mathrm{~A} / \mathrm{g}$, a maximum energy of $22.2 \mathrm{Wh} / \mathrm{kg}$ at a power of $400 \mathrm{~W} / \mathrm{kg}$ and cycling stability $(94.2 \%$ of the initial capacitance after 5000 cycles).
As a result of hydrothermal synthesis carried out by the authors [38] $\mathrm{NiMoO}_{4}$ nanoplates are formed directly on the surface of the substrate of carbon fabric (Fig. 4). The composite-based electrode exhibits exceptional electrochemical properties in the aqueous electrolyte, reaches a specific capacity of $1500 \mathrm{C} / \mathrm{g}$ at $5 \mathrm{~A} / \mathrm{g}$ and demonstrates excellent stability of $94.63 \%$ after 5000 

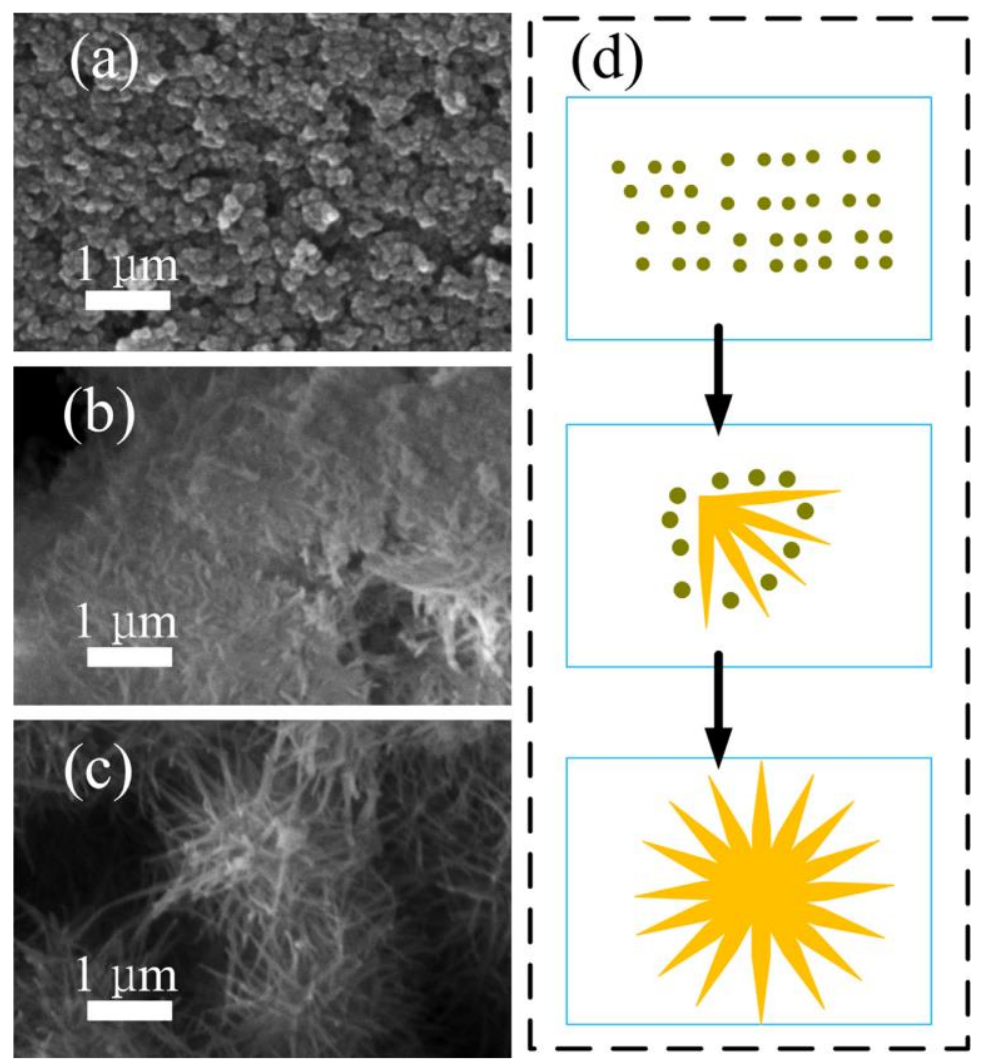

Fig.5. SEM images of products at different stages (a) $2 \mathrm{~min}$, (b) $3 \mathrm{~min}$, (c) 6 min and (d) the formation mechanism of the $\mathrm{NiMoO}_{4} \cdot \mathrm{H}_{2} \mathrm{O}$ nanoclusters [42].

charge / discharge cycles.

\section{Microwave synthesis and ultrasonic material dispersion}

A great deal of attention should be paid to the methods where nanoparticles are formed as the result of different physical actions, for example, microwaves and ultrasonic activities. These activities inhibit chemical reactions leading to material forming with necessary microstructure, phase composition and unique functional properties [39]. Thus, at ultrasonic dispersion the reduction of particles takes place and uncompensated connections, able to interconnect actively with electrolyte ions appear on the surface [40]. Another direction is the use of ultrasonic sound during nanoparticles synthesis and subsidence. Microwave heating - is the process when materials interact with microwaves (the frequency range is from $300 \mathrm{MHz}$ to $300 \mathrm{GHz}$ ), deposit per volume and transform it into heat. At ordinary heating the upper part of material is heated first, then its middle part, meaning that the heat gradient is present [41]. At microwave synthesis high temperature heating takes place within the middle of a sample. Besides, the given method promotes homogeneous dispersion of ultra-small nanoparticles, enhances diffusion processes, lowers consolidation temperature and is environmentally safe.

In [42], a typical process for producing nickel molybdate involved dissolving an equal molar ratio of $\mathrm{Ni}\left(\mathrm{NO}_{3}\right)_{2}$ and $\mathrm{Na}_{2} \mathrm{MoO}_{4} \cdot 2 \mathrm{H}_{2} \mathrm{O}$ in distilled water, followed by microwave heating. The authors compared the time of microwave exposure (for $1-6 \mathrm{~min}$ ) on the morphology of the final materials. It was found that after 2 min of heating, homogeneous nanoparticles with a size of $100 \mathrm{~nm}$ are formed. Nanorods are formed after $3 \mathrm{~min}$ of heating, and after $6 \mathrm{~min}$ obtained nanoclusters of $\mathrm{NiMoO}_{4} \cdot \mathrm{H}_{2} \mathrm{O}$ (Fig. 5). NiMoO${ }_{4} \cdot \mathrm{H}_{2} \mathrm{O}$ nanoclusters were $3 \mu \mathrm{m}$ in size and consisted of one-dimensional nanorods $1 \mu \mathrm{m}$ long and $100 \mathrm{~nm}$ in diameter. The electrode material based on nickel molybdate reached a specific capacitance of $680 \mathrm{~F} / \mathrm{g}$ at a current of $1 \mathrm{~A} / \mathrm{g}$, Coulomb efficiency was $98 \%$ after 1000 cycles.

The authors [43] performed microwave synthesis, in which nanoflakes $\mathrm{NiMoO}_{4}$ received and investigated the effect of heating time on the physical and chemical characteristics of the samples, however, compared with [42], the heating time was increased to 5, 10 and 15 minutes. As a result, anisotropic structures were obtained at the lowest exposure time, while a further increase in time led to the formation of flaky morphology, possibly due to the self-organization of anisotropic nuclei. The material obtained by $15 \mathrm{~min}$ microwave heating showed the best electrochemical properties. This is due to higher specific surface area $\sim 39 \mathrm{~m}^{2} / \mathrm{g}$ while the specific capacitance was $1650 \mathrm{~F} / \mathrm{g}$ and kept 3.000 cycles. Electrochemical studies of the electrode based on $\mathrm{NiMoO}_{4}$ nanorods (heating time $10 \mathrm{~min}$ ) [44] showed specific capacitance of $450 \mathrm{~F} / \mathrm{g}$ at a current of $2 \mathrm{~mA} / \mathrm{cm}^{2}$ and Coulomb efficiency of $94 \%$ after 1000 cycles.

To obtain a nanocomposite $\mathrm{NiMoO}_{4}-\mathrm{rGO}$ a microwave method was used [45], in which graphene oxide (GO), $\mathrm{NiCl}_{2} \cdot 6 \mathrm{H}_{2} \mathrm{O}$ and $\left(\mathrm{NH}_{4}\right)_{6} \mathrm{Mo}_{7} \mathrm{O}_{2} \cdot 4 \mathrm{H}_{2} \mathrm{O}$ were sonicated in distilled water with the addition $\mathrm{CO}\left(\mathrm{NH}_{2}\right)_{2}$. 


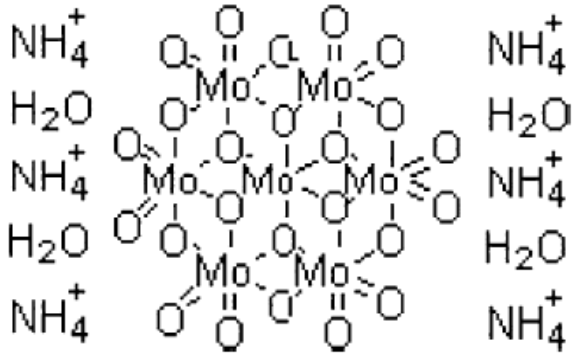

Fig.6. Chemical structure of ammonium heptamolybdate molecule.

$\mathrm{Mo}_{7} \mathrm{O}_{2}{ }^{6-}$ spontaneously converted to $\mathrm{MoO}_{4}{ }^{2-}$ in an alkaline medium. During microwave exposure, graphene oxide was reduced, while $\mathrm{Ni}^{2+}$ and $\mathrm{MoO}_{4}{ }^{2-}$ ions formed nanorods $\mathrm{NiMoO}_{4}$. The $\mathrm{NiMoO}_{4}$-rGO composite electrode showed high specific capacitance $(1274 \mathrm{~F} / \mathrm{g}$ at $1 \mathrm{~A} / \mathrm{g})$, lower resistance, and better rate capability $(81.1 \%$ of the initial specific capacitance after 1000 cycles) compared to pure $\mathrm{NiMoO}_{4}$ in a three-electrode cell. In addition, the asymmetric capacitor based on $\mathrm{NiMoO}_{4}$-rGO reached a voltage of $1.5 \mathrm{~V}$ and an energy of $30.3 \mathrm{Wh} / \mathrm{kg}$ at a power of $187 \mathrm{~W} / \mathrm{kg}$. The improved electrochemical characteristics of the composite are mainly related to mesoporous $\mathrm{NiMoO}_{4}$ nanorods with a large specific surface area and rGO conductivity.

It is efficient to use ultrasonic sound at frequency of $20-25 \mathrm{kHz}$ [40]. Within some liquid the ultrasonic sound creates periodic domains of high and low pressure. The forces that influence liquid molecules become stronger than intermolecular interaction due to significant reduction of hydrostatic impact. As a result the smallest bubbles emerge with their consequent popping. The process is accompanied by creating shock waves with high pressure of $5-50 \cdot 10^{6} \mathrm{~Pa}$ and high temperature up to $500{ }^{\circ} \mathrm{C}$. The increased temperature and pressure inhibit the inner creation of free hydrogen $\mathrm{H}$ and hydroxyl $\mathrm{OH}$ radicals [46]:

$$
\mathrm{H}_{2} \mathrm{O} \rightarrow \cdot \mathrm{H}+{ }^{\cdot} \mathrm{OH}
$$

These radicals either recombine producing hydrogen and hydrogen peroxide or interact with the molecules of dissolved substance, which in this way either restore or oxidize:

$$
\begin{gathered}
\cdot \mathrm{H}+{ }^{\cdot} \mathrm{H} \rightarrow \mathrm{H}_{2} \\
\mathrm{OH}+\mathrm{OH} \rightarrow \mathrm{H}_{2} \mathrm{O}_{2}
\end{gathered}
$$

Typically, ammonium heptamolybdate is used in the production of molybdenum compounds as a precursor (Fig. 6). Since molybdate is stable only in alkaline medium and $\left(\mathrm{NH}_{4}\right)_{6} \mathrm{Mo}_{7} \mathrm{O}_{2} \cdot 4 \mathrm{H}_{2} \mathrm{O}$ converted into molybdenum oxide at low $\mathrm{pH}$ and heating to $90{ }^{\circ} \mathrm{C}$ [47] according to the reaction:

$$
\left(\mathrm{NH}_{4}\right)_{6} \mathrm{Mo}_{7} \mathrm{O}_{24} \cdot 4 \mathrm{H}_{2} \mathrm{O} \rightarrow \mathrm{MoO}_{3}+6 \mathrm{NH}_{3}+7 \mathrm{H}_{2} \mathrm{O} \text {. }
$$

The resulting oxide reacts with hydrogen peroxide $\left(\mathrm{H}_{2} \mathrm{O}_{2}\right)$ formed during the ultrasonic dispersion and converted into molybdic acid $\left(\mathrm{H}_{2} \mathrm{MoO}_{5}\right)$ [48]. As a result, the reaction of molybdic acid with nickel ions gives $\mathrm{NiMoO}_{4}$ [49]. In study [50], nanostructures of nickel molybdate were obtained by the reaction between $\mathrm{Ni}\left(\mathrm{CH}_{3} \mathrm{COO}\right)_{2} \cdot 4 \mathrm{H}_{2} \mathrm{O}$ and $\left(\mathrm{NH}_{4}\right)_{6} \mathrm{Mo}_{7} \mathrm{O}_{24} \cdot 4 \mathrm{H}_{2} \mathrm{O}$ at low temperature and ultrasonicaction. The authors investigated the influence of time and power of ultrasonic dispersion, $\mathrm{pH}$ level, surfactant, concentration of initial precursors. The results show that that optimal conditions for obtaining nanorods are power of $75 \mathrm{~W}$ and time of $30 \mathrm{~min}, \mathrm{pH} 6.5$.

\section{Chemical precipitation method}

As a rule, stoichiometric $\mathrm{NiMoO}_{4}$ is obtained by total deposition with the use of aqueous solutions of nickel nitrate and ammonium heptamolybdate [51] or molybdic acid $[49,52,53]$. The properties of the material acquired in this manner depend on the preparation conditions, namely on the concentration of reacting ions in the solution, temperature, $\mathrm{pH}$ and residual matter aging period.

In [54, 55], nickel molybdate was obtained by chemical deposition at temperatures of $70-85^{\circ} \mathrm{C}$ followed by heat treatment in the temperature range of $300-1000^{\circ} \mathrm{C}$. The hydrated phase obtained at a temperature of $70^{\circ} \mathrm{C}$ had a triclinic structure. Samples calcined at $300{ }^{\circ} \mathrm{C}$ consisted of mixture of hydrated and alpha phases, while in samples calcined from 400 to $600{ }^{\circ} \mathrm{C}$ alpha and beta polymorphs were present. Only samples calcined at temperatures above $700{ }^{\circ} \mathrm{C}$ (Fig. 7)

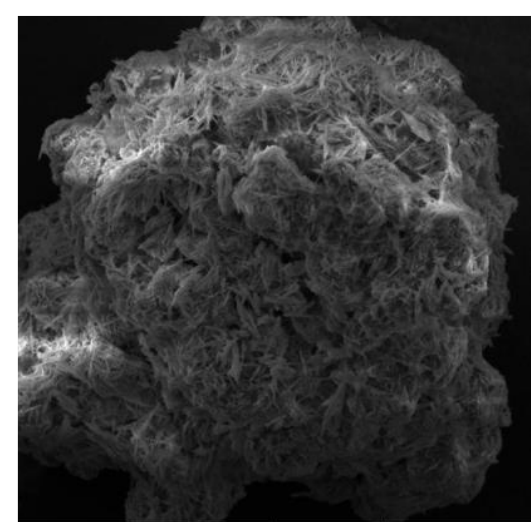

a

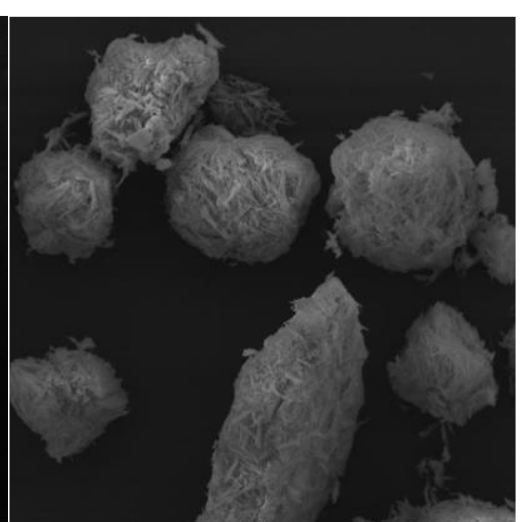

b

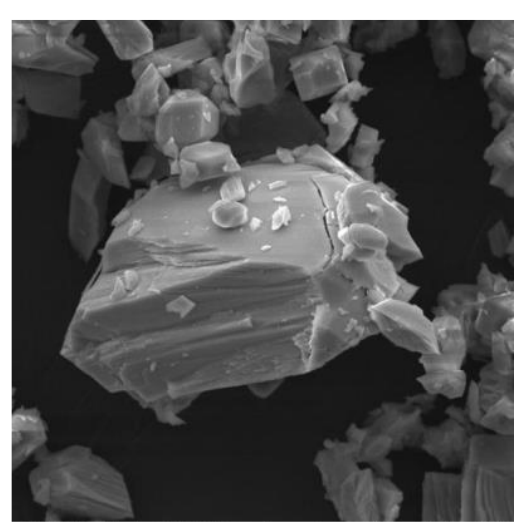

c

Fig.7. Typical SEM images of $\mathrm{NiMoO}_{4}$ prepared at different temperatures: (a) $70{ }^{\circ} \mathrm{C}$, (b) $400{ }^{\circ} \mathrm{C}$, and (c) $1000{ }^{\circ} \mathrm{C}[55]$. 


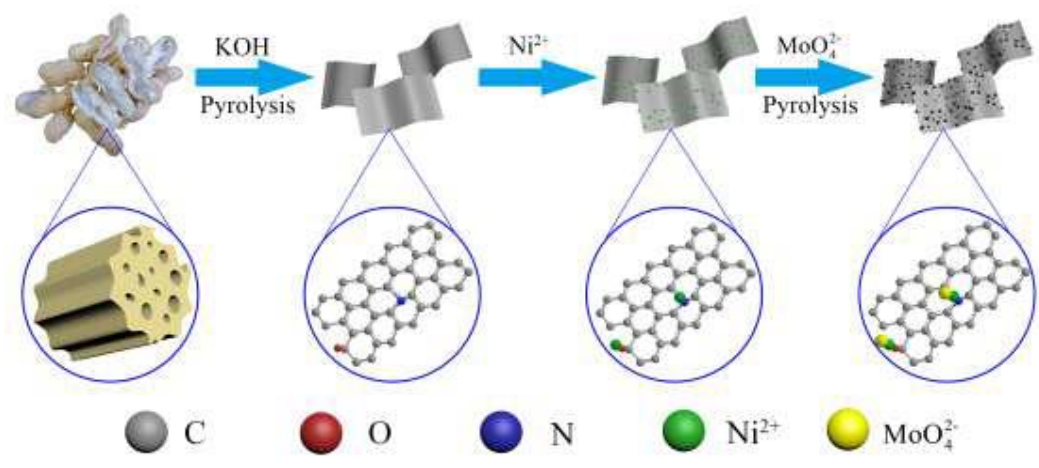

Fig.8. Conceptual scheme for the synthesis of $\mathrm{NiMoO}_{4}$ embedded in carbon nanosheets derived from peanut shells [56].

crystallized into a pure $\beta$-phase with a monoclinic structure corresponding to the space group $C 2 / m$ (\#12) [55].

In [56], nanoporous carbon sheets from peanut shells and $\mathrm{NiMoO}_{4}$ nanoparticles were obtained. The scheme of synthesis is shown in Fig. 8.

The peanut shell was carbonized and activated with $\mathrm{KOH}$ in an argon atmosphere at high temperature. $\mathrm{Ni}^{2+}$ ions are easily adsorbed on the surface of carbon nanosheets due to the presence of large number of oxygen and nitrogen-containing functional groups. Oppositely charged $\mathrm{MoO}_{4}{ }^{2-}$ ions are also adsorbed after adsorption of $\mathrm{Ni}^{2+}$ ions. $\mathrm{NiMoO}_{4}$ nanoparticles embedded in carbon nanosheets had an average size of $10 \mathrm{~nm}$.

\section{Other obtaining methods}

It has been informed in investigations [57, 58] about obtaining nickel molybdate nanocrystals by microemulsion method. Microemulsion system consisted of cationic surfactant CTAB, butanol-1, isooctane as oil phase and aqueous solutions of nickel chloride and sodium molybdate. Stoichiometric addition of $\mathrm{MoO}_{4}{ }^{2-}$ to microemulsion with $\mathrm{Ni}^{2+}$ ions leads to the formation of $\mathrm{NiMoO}_{4}$ precipitation with inverted micelle. CTAB stabilizes nanoparticles by limiting their outer surface. Organic shells, absorbed at outer material surface keep nanoparticles apart from each other, preventing Van der Waals interaction between them (Fig. 9).

Mechano-chemical activation is one of the simplest methods of obtaining nickel molybdate. Thus, nanosized crystallites were obtained in [59] by intensive mechanical treatment with a ball mill of a stoichiometric mixture of $\mathrm{NiO}$ and $\mathrm{MoO}_{3}$ for different times, namely from 2.5 to 5 hours. The sample, mechanically activated for $2.5 \mathrm{~h}$, was annealed in the temperature range $350-450{ }^{\circ} \mathrm{C}$ for $20 \mathrm{~h}$. Non-mechanical activated mixture directly subjected to heat treatment at $700{ }^{\circ} \mathrm{C}$ for solid-state reaction between $\mathrm{NiO}$ and $\mathrm{MoO}_{3}$. As a result, it was found that $5 \mathrm{~h}$ grinding of the reagents led to complete crystallization into single-phase $\alpha-\mathrm{NiMoO}_{4}$ at room temperature. Mechano-chemical activation for $2.5 \mathrm{~h}$ leads to the formation of a high-temperature phase $\beta-\mathrm{NiMoO}_{4}$. The authors of [60] obtained nanomaterials $\mathrm{NiMoO}_{4} \cdot \mathrm{xH}_{2} \mathrm{O}$, $\beta-\mathrm{NiMoO}_{4}$ and $\alpha-\mathrm{NiMoO}_{4}$ by solid-state reaction without organic solvent, namely by grinding nickel nitrate with sodium molybdate in a molar ratio of $1: 1$ for 1 hour. After washing with distilled water, the samples were calcined at $400{ }^{\circ} \mathrm{C}$ and $700{ }^{\circ} \mathrm{C}$ to obtain $\alpha$ and $\beta$ phases, respectively. The obtained nanorods $\beta-\mathrm{NiMoO}_{4}$ show a higher specific capacitance $(1415 \mathrm{~F} / \mathrm{g})$ compared to nanorods $\mathrm{NiMoO}_{4} \cdot \mathrm{xH}_{2} \mathrm{O}(777.5 \mathrm{~F} / \mathrm{g})$ and nanoplates $\alpha-\mathrm{NiMoO}_{4} \quad(555 \mathrm{~F} / \mathrm{g})$ at $1 \mathrm{~A} / \mathrm{g}$. The asymmetric supercapacitor based on $\beta-\mathrm{NiMoO}_{4} / \mathrm{rGO}$ reached energy
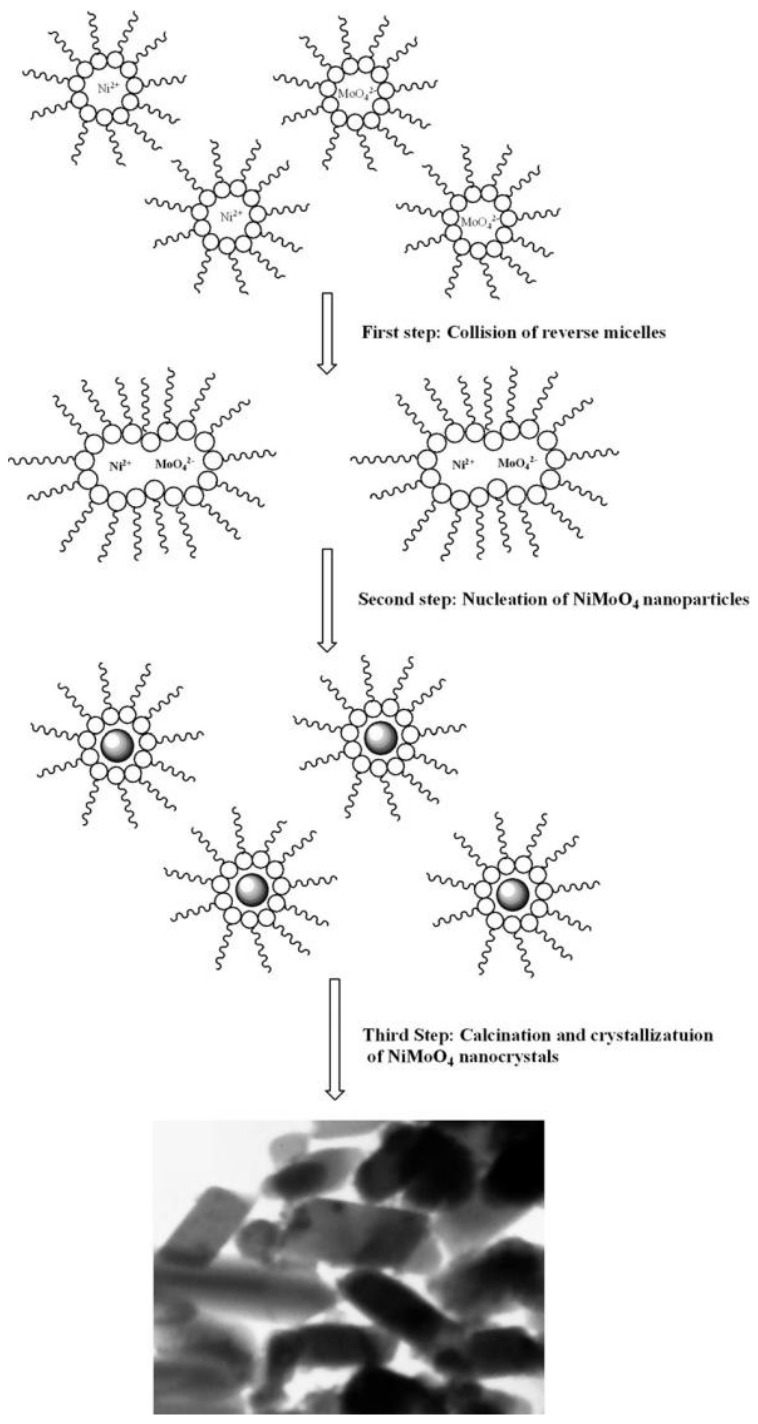

Fig.9. Schematic representation of all stages involved in the synthesis of $\mathrm{NiMoO}_{4}$ nanocrystal [57]. 
of $29,3 \mathrm{Wh} / \mathrm{kg}$ at power of $187 \mathrm{~W} \mathrm{~kg}$.

The research work [19, 55] performed sol-gel synthesis with the use of ammonium molybdate, nickel nitrate, citric acid and ethylcellulose as SAS. At first preparation stage aqueous solutions of precursors and aqueous solution of ethylcellulose are mixed at $50{ }^{\circ} \mathrm{C}$ for sol formation. Then the sol is heated up to $90{ }^{\circ} \mathrm{C}$, mixing it constantly until the gel is obtained. Afterwards the gel is dried at higher than $105^{\circ} \mathrm{C}$. As a result we received pure single-phase $\mathrm{NiMoO}_{4}$ with monoclinic structure and nanoparticles sized $20-30 \mathrm{~nm}$.

\section{Conclusion}

The research work classified modern methods of obtaining nickel molibdates and composites with carbon material on their basis. We have analyzed the fundamental stages of hydrothermal, microwave synthesis, ultrasonic dispersion, mechano-chemical, solgel method and chemical precipitation method. On the basis of the literature data we have displayed the influence results of different synthesis conditions on phase structure, morphology, physical and electrochemical properties of material and conducted comparison of power output features of these materials in the capacity of supercapacitors electrodes.

Popovych O.M. - Doctoral student of the Department of Materials Science and New Technologies;

Budzulyak I.M. - Professor, Doctor of Physical and Mathematical Sciences, Professor of the Department of Materials Science and New Technologies;

Kotsyubynsky V.O. - Professor, Doctor of Physical and Mathematical Sciences, Professor of the Department of Materials Science and New Technologies;

Popovych O.V. - PhD student of the Department of Materials Science and New Technologies;

Rachiy B.I. - Professor, Doctor of Physical and Mathematical Sciences, Professor of the Department of Materials Science and New Technologies;

Ilnytskyi R.V. - Professor, Doctor of Physical and Mathematical Sciences, Professor of the Department of Materials Science and New Technologies;

Yablon L.S. - Professor, Doctor of Physical and Mathematical Sciences, Professor of the Department of Physics and Methods of Teaching.

[1] O.M. Khemii, I.M. Budzuliak, V.O. Kotsyubynsky, L.S. Yablon, R.V. Ilnytskyi, V.M. Boychuk, O.V. Morushko, K.V. Bandura, M.M. Khemii, Materials Science-Poland 37(4), 547 (2019) (DOI: https://doi.org/10.2478/msp-2019-0077).

[2] L.S. Yablon, I.M. Budzulyak, M.V. Karpets, V.V. Strelchuk, S.I. Budzulyak, I.P. Yaremiy, O.M. Hemiy, O.V. Morushko, J. Nano- Electron. Phys. 8(2), 02029 (2016) (DOI: https://doi.org/10.21272/jnep.8(2).02029).

[3] G. Jiang, L. Li, Z. Xie, B. Cao, Ceramics International 45(15), 18462 (2019) (DOI: https://doi.org/10.1016/j.ceramint.2019.06.064).

[4] L.S. Yablon, I.M. Budzulyak, O.V. Morushko, R.V. Ilnythky, O.M. Hemiy, and A.I. Kachmar, Nanosistemi, Nanomateriali, Nanotehnologii 15(4), 741 (2017) (DOI: https://doi.org/10.15407/nnn.15.04.0741).

[5] S.L. Revo, I.M. Budzulyak, B.I. Rachiy, M.M. Kuzishin, Surf. Engin. Appl. Electrochem 49, 68 (2013) (DOI: https://doi.org/10.3103/S1068375513010122).

[6] H. Fang, L.S. Zhang, Y.L. Xing, S.C. Zhang, S.D. Wu, Int. J. Electrochem. Sc. 13(9), 8736 (2018) (DOI: https://doi.org/10.20964/2018.09.21).

[7] Z. Liu, Y. Zhang, J. Feng, Q. Han, Q. Wei, Sensors and Actuators B: Chemical 287, 551 (20 19) (DOI: https://doi.org/10.1016/j.snb.2019.02.079).

[8] O.M. Hemiy, I.M. Budzulyak, L.S. Yablon, D.I. Popovych, O.V. Morushko, Nanosistemi, Nanomateriali, $\begin{array}{llll}\text { Nanotehnologii } & 14(1), & 147 & \text { (2016) }\end{array}$ https://www.imp.kiev.ua/nanosys/media/pdf/2016/1/nano_vol14_iss1_p0147p0155_2016.pdf).

[9] Z.S. Wu, D.W. Wang, W. Ren, J. Zhao, G. Zhou, F. Li, H.M. Cheng, Advanced Functional Materials 20(20), 3595 (2010) (DOI: https://doi.org/10.1002/adfm.201001054).

[10] M. Toupin, T. Brousse, D. Belanger, Chem. Mater. 16(16), 3184 (2004) (DOI: https://doi.org/10.1021/cm049649j).

[11] M.H. Bai, L.J. Bian, Y. Song, X.X. Liu, ACS Appl. Mater. Interfaces 6(15) 12656 (2014) (DOI: https://doi.org/10.1021/am502630g).

[12] L.S. Yablon, V.V. Strelchuk, I.M. Budzulyak, S.I. Budzulyak, O.V. Morushko, B.I. Rachiy, O.M. Hemiy, J. Nano- $\quad$ Electron. $\quad$ Phys. $\quad 7(3), \quad 03016 \quad$ (2015) https://jnep.sumdu.edu.ua/download/numbers/2015/3/articles/jnep_2015_V7_03016.pdf).

[13] I.M. Budzulyak, O.M. Khemii, O.V. Morushko, D.I. Popovych, Yu. Starchuk, L.S. Yablon, Nanosistemi, $\begin{array}{lllll}\text { Nanomateriali, } & \text { Nanotehnologii } & 17(4), & 0689 & \text { (2019), }\end{array}$ https://www.imp.kiev.ua/nanosys/media/pdf/2019/4/nano_vol17_iss4_p0689p0700_2019.pdf).

[14] X. Xia, W. Lei, Q. Hao, W. Wang, X. Wang, Electrochim. Acta 99, 253 (2013) (DOI: https://doi.org/10.1016/j.electacta.2013.03.131).

[15] K. Seevakan, A. Manikandan, P. Devendran, A. Baykal, T. Alagesan, Ceram. Int. 44(15), 17735(2018) (DOI: https://doi.org/10.1016/j.ceramint.2018.06.240). 
O.M. Popovych, I.M. Budzulyak, V.O. Kotsyubynsky, O.V. Popovych, B.I. Rachiy, R.V. Ilnytskyi, L.S. Yablon

[16] P.R. Jothi, K. Shanthi, R.R. Salunkhe, M. Pramanik, V. Malgras, S.M. Alshehriand, Y. Yamauchi, Eur. J. Inorg. Chem. 22, 3694 (2015) (DOI: https://doi.org/10.1002/ejic.201500410).

[17] G. Kianpour, F. Soofivand, M. Badiei, M. S-. Niasariand M. Hamadanian, J. Mater. Sci.: Mater. Electron. 27, 10244 (2016) (DOI: https://doi.org/10.1007/s10854-016-5103-3 ).

[18] P.R. Jothi, S. Kannanand G. Velayutham, J. Power Sources 277, 350 (2015) (DOI: https://doi.org/10.1016/j.jpowsour.2014.11.137).

[19] V. Umapathy, P. Neeraja, A. Manikandanand P. Ramu, Trans. Nonferrous Met. Soc. China 27(8), 1785 (2017) (DOI: https://doi.org/10.1016/S1003-6326(17)60201-2).

[20] S.F. Matar, A. Largeteauand G. Demazeau, Solid State Sci. 12(10), 1779 (2010) (DOI: https://doi.org/10.1016/j.solidstatesciences.2010.07.030).

[21] A.W. Sleight, Acta Cryst. B 28, 2899 (1972) (DOI: https://doi.org/10.1107/S0567740872007186).

[22] G. Boopathy, M. Keerthi, S.-M. Chen, M. Umapathy, B.N. Kumar, Mater.Chem. Phys. 239, 121982 (2020) (DOI: https://doi.org/10.1016/j.matchemphys.2019.121982).

[23] G.W. Smith, Acta Crystallographica, $15(10), \quad 1054 \quad$ (1962) (DOI: https://doi.org/10.1107/S0365110X62002765).

[24] A.W. Sleight, B.L. Chamberland, Inorganic Chemistry 7(8), 1672 (1968) (DOI: https://doi.org/10.1021/ic50066a050).

[25] M. Wiesmann, H. Ehrenberg, G. Wltschek, P. Zinn, H. Weitzel, H. Fuess, Journal of magnetism and magnetic materials 150(1), L1 (1995) (DOI: https://doi.org/10.1016/0304-8853(95)00516-1).

[26] J.A. Rodriguez, S. Chaturvedi, J.C. Hanson, J.L. Brito, The Journal of Physical Chemistry B 103(5), 770 (1999) (DOI: https://doi.org/10.1021/jp983115m).

[27] Y. Huang, F. Cui, Y. Zhao, J. Lian, J. Bao, H. Li, J. Alloys Compd. 753, 176 (2018) (DOI: https://doi.org/10.1016/j.jallcom.2018.04.060).

[28] Y. Zhang, H.-L. Gao, X.-D. Jia, S.-W. Wang, J. Yan, H.-W. Luo, K.-Z. Gao, H. Fang, A.-Q. Zhang, L.-Z. Wang, J. Renew. Sustain. Ener. 10, 054101 (2018) (DOI: https://doi.org/10.1063/1.5032271).

[29] H. Xuan, Y. Xu, Y. Zhang, H. Li, P. Han, Y. Du, J. Alloys Compd. 745, 135 (2018) (DOI: https://doi.org/10.1016/j.jallcom.2018.02.172).

[30] Y. Ding, Y. Wan, Y.L. Min, W. Zhang, S.H. Yu, Inorganic Chemistry, 47(17), 7813 (2008) (DOI: https://doi.org/10.1021/ic8007975).

[31] D. Cai, D. Wang, B. Liu, Y. Wang, Y. Liu, L. Wang, T. Wang, ACS applied materials \& interfaces 5(24), 12905 (2013) (DOI: https://doi.org/10.1021/am403444v).

[32] S. Peng, L. Li, H.B. Wu, S. Madhavi, X.W. Lou, Advanced Energy Materials 5(2), 1401172 (2015) (DOI: https://doi.org/10.1002/aenm.201401172).

[33] B. Senthilkumar, R.K. Selvan, Journal of colloid and interface science 426, 280 (2014) (DOI: https://doi.org/10.1016/j.jcis.2014.04.010).

[34] L. Lin, T. Liu, J. Liu, R. Sun, J. Hao, K. Ji, Z, Applied Surface Science 360(A), 234(2016) (DOI: https://doi.org/10.1016/j.apsusc.2015.11.018).

[35] N.S. Neeraj, B. Mordina, A.K. Srivastava, K. Mukhopadhyay, N.E. Prasad, Applied Surface Science 473, 807 (2019) (DOI: https://doi.org/10.1016/j.apsusc.2018.12.220).

[36] E.R. Ezeigwe, P.S. Khiew, C.W. Siong, M.T. Tan, Ceramics International 43(16), 13772 (2017) (DOI: https://doi.org/10.1016/j.ceramint.2017.07.092).

[37] X. Feng, J. Ning, D. Wang, J. Zhang, M. Xia, Y. Wang, Y. Hao, Journal of Alloys and Compounds 816, 152625 (2020) (DOI: https://doi.org/10.1016/j.jallcom.2019.152625).

[38] Y. Abbas, S. Yun, M.S. Javed, J. Chen, M.F. Tahir, Z. Wang, Z. Hussain, Ceramics International 46(4), 4470(2020) (DOI: https://doi.org/10.1016/j.ceramint.2019.10.173).

[39] O.P. Bolade, A.B. Williams, N.U. Benson, Environmental Nanotechnology, Monitoring \& Management 13, 100279 (2020) (DOI: https://doi.org/10.1016/j.enmm.2019.100279).

[40] I.M. Budzulyak, L.S. Yablon, R.V. Ilnytskyi, O.V. Morushko, O.M. Hemiy, J. Nano- Electron. Phys. 10(2), 02016 (2018) (DOI: https://doi.org/10.21272/jnep.10(2).02016).

[41] M. Oghbaei, O. Mirzaee, Journal of alloys and compounds 494(1-2), 175(2010) (DOI: https://doi.org/10.1016/j.jallcom.2010.01.068).

[42] H. Wan, J. Jiang, X. Ji, L. Miao, L. Zhang, K. Xu, Y. Ruan, Materials Letters 108, 164 (2013). (DOI: https://doi.org/10.1016/j.matlet.2013.06.099).

[43] A. Ajay, A. Paravannoor, J. Joseph, V. Amruthalakshmi, S.S. Anoop, S.V. Nair, A. Balakrishnan, Applied Surface Science, 326, 39 (2015) (DOI: https://doi.org/10.1016/j.apsusc.2014.11.016).

[44] K. Seevakan, A. Manikandan, P. Devendran, A. Shameem, T. Alagesan, Ceramics International 44(12), 13879 (2018) (DOI: https://doi.org/10.1016/j.ceramint.2018.04.235).

[45] T. Liu, H. Chai, D. Jia, Y. Su, T. Wang, W. Zhou, Electrochimica Acta 180, 998 (2015) (DOI: https://doi.org/10.1016/j.electacta.2015.07.175).

[46] A. Henglein, Ultrasonics 25(1), 6 (1987) (DOI: https://doi.org/10.1016/0041-624X(87)90003-5).

[47] D. Parviz, M. Kazemeini, A.M. Rashidi, K.J. Jozani, Journal of Nanoparticle Research 12(4), 1509(2010) (DOI: https://doi.org/10.1007/s11051-009-9727-6). 
[48] R.N. Panda, S. Kaskel, Journal of materials science 41(8), 2465(2006) (DOI: https://doi.org/10.1007/s10853006-5112-3).

[49] M. Sautel, G. Thomas, A. Kaddouri, C. Mazzocchia, R. Anouchinsky, Applied Catalysis A: General 155(2), 217 (1997) (DOI: https://doi.org/10.1016/S0926-860X(96)00401-2).

[50] G. Kianpour, M. Salavati-Niasari, H. Emadi, Ultrasonics sonochemistry 20(1), 418 (2013) (DOI: https://doi.org/10.1016/j.ultsonch.2012.08.012).

[51] C. Mazzocchia, C. Aboumrad, C. Diagne, E. Tempesti, J.M. Herrmann, G. Thomas, Catalysis Letters 10(3-4), 181(1991) (DOI: https://doi.org/10.1007/BF00772070).

[52] F. Di Renzo, C. Mazzocchia, Thermochimica Acta 85, 139 (1985) (DOI: https://doi.org/10.1016/00406031(85)85549-0).

[53] O. Lezla, E. Bordes, P. Courtine, G. Hecquet, Journal of Catalysis 170(2), 346(1997) (DOI: https://doi.org/10.1006/jcat.1997.1759).

[54] M.V. da Silva, D.F. de Oliveira, H.S. Oliveira, K.P. Siqueira, Materials Research Bulletin 122, 110665 (2020) (DOI: https://doi.org/10.1016/j.materresbull.2019.110665).

[55] A. Kaddouri, E. Tempesti, C. Mazzocchia, Materials Research Bulletin 39(4-5), 695 (2004) (DOI: https://doi.org/10.1016/j.materresbull.2003.11.005).

[56] M. Yang, Q. Bai, C. Ding, Colloids and Surfaces A: Physicochemical and Engineering Aspects 604, 125276 (2020) (DOI: https://doi.org/10.1016/j.colsurfa.2020.125276).

[57] M. Masteri-Farahani, S. Mahdavi, M. Rafizadeh, Ceramics International 39(4), 4619(2013) (DOI: https://doi.org/10.1016/j.ceramint.2012.11.059).

[58] Y. Mi, Z. Huang, F. Hu, J. Jiang, Y. Li, Materials Letters 64(6), 695(2010) (DOI: https://doi.org/10.1016/j.matlet.2009.12.041).

[59] D. Klissurski, M. Mancheva, R. Iordanova, G. Tyuliev, B. Kunev, Journal of alloys and compounds 422(1-2), 53 (2006) (DOI: https://doi.org/10.1016/j.jallcom.2005.11.073).

[60] X. Lu, W. Jia, H. Chai, J. Hu, S. Wang, Y. Cao, Journal of colloid and interface science 534, 322 (2019) (DOI: https://doi.org/10.1016/j.jcis.2018.09.042).

О.М. Попович, І.М. Будзуляк, В.О. Коцюбинський, О.В. Попович, Б.І. Рачій, Р.В. Ільницький, Л.С. Яблонь

\section{Методи отримання молібдатів нікелю та композитів молібдат/ вуглецевий матеріал для електродів гібридних суперконденсаторів}

Прикарпатський національний університет імені Василя Стефаника, Івано-Франківськ, Украӥна, kheтіiolha@ gтаil.com

\footnotetext{
Молібдат нікелю завдяки своїй електронній конфігурації, стабільній кристалічній структурі, окисновідновній поведінці демонструє чудові фізико-хімічні властивості та відносно високу електропровідність, що в сукупності дозволяє матеріалу демонструвати високу питому потужність. У роботі здійснено класифікацію сучасних методів отримання молібдатів нікелю та композитів з вуглецевим матеріалом на їх основі. Проаналізовано основні етапи гідротермального, мікрохвильового синтезів, ультразвукового диспергування, механохімічного, золь-гель методу та хімічного осадження. Показано вплив різних умов синтезу на фазову структуру, морфологію, фізичні та електрохімічні властивості матеріалу.

Ключові слова: молібдат нікелю, суперконденсатор, синтез, питома ємність, вуглецевий матеріал.
} 